Southern Methodist University

SMU Scholar

Faculty Journal Articles and Book Chapters

Faculty Scholarship

1978

\title{
United States Securities Laws: A Transnational Perspective
}

Joseph J. Norton

Southern Methodist University, Dedman School of Law

\section{Recommended Citation}

Joseph J. Norton, United States Securities Laws: A Transnational Perspective, 7 ANGLO-AM. L. REV. 81 (1978)

This document is brought to you for free and open access by the Faculty Scholarship at SMU Scholar. It has been accepted for inclusion in Faculty Journal Articles and Book Chapters by an authorized administrator of SMU Scholar. For more information, please visit http://digitalrepository.smu.edu. 
UNITED STATES SECURITIES LAWS:

\author{
A TRANSNATIONAL PERSPECTIVE
}

\author{
By JOSEPH JUDE NORTON*
}

In recent years a dramatic increase has occurred in transnational business transactions coming within the purview of the United States federal securities laws. For example, under separate studies precipitated by the Foreign Investment Study Act of 1974, the U.S. Treasury Department concluded that for the year 1975 foreigners invested \$86 million in U.S. stocks, corporate securities and Government securities, and the U.S. Commerce Department found that foreign direct investment in the U.S. amounted to $\$ 26.5$ billion at the end of 1974 . These studies, however, do not reflect the number or dollar amount of many transnational business transactions, which to the non-U.S. businessman or attorney appear at first blush to be purely commercial in nature, but which under U.S. federal securities laws would be characterized as securities.

This article shall endeavor to set some perimeters respecting two fundamental problems concerning the applicability of United States federal securities laws to foreign business activities: (i) the extent the term "security" for purposes of federal securities laws may apply to business transactions and (ii) the extent that the federal securities laws may extend subject-matter jurisdiction over activities of foreign individuals and business entities. In conclusion, a brief discussion will be made of the main registration exemptions and civil liabilities under the federal securities laws. ${ }^{1}$

*LL.B. (Edin.), LL.M. (Texas), S.J.D. (Michigan), Diplome (droit prive) (Hague); Attorney, Dallas, Texas; Lecturer, Southern Methodist University Law School

1. For purposes of this study, the following major works will be cited as follows:

(i) Bureau of National Affairs, Securities Regulation and Law Report, a weekly synopsis of major legal and accounting developments in securities law, hereinafter $B N A$ Sec.Reg. \& L. Rep..

(ii) Commerce Clearing House, Inc., Federal Securities Law Reporter, hereinafter CCH Fed.Sec.L.Rep..

(iii) Jennings and Marsh, Securities Regulation (1972, as supplemented), hereinafter Jennings and Marsh.

(iv) Loss, Securities Regulation, -6 volumes (1961 as supplemented), hereinafter Loss. 
I.

\section{Introduction}

Historical Perspective. Federal securities laws have primarily evolved around six federal statutes, the most significant of which for present purposes are the Securities Act of 1933 ("1933 Act") and the Securities Exchange Act of 1934 ("1934 Act"). ${ }^{2}$

From the vantage point of the non-American, it is perhaps striking that the first piece of federal securities legislation did not gestate until 1933, following closely upon the heels of the dramatic 1929 stock market crash. The United Kingdom, France and Germany already had embodied in their corporation codes provisions pertaining to disclosure in securities transactions. In fact, securities legislation had existed in most of the states of the United States prior to enactment of the 1933 Act; such state legislation is commonly dubbed "blue sky laws." 3

A notable characteristic of the federal securities laws is that they are not, unlike their European counterparts, incorporated within any general corporation code, but stand distinct and apart from the development of the general body of corporation laws. This dichotomy is due largely to the fact that there does not exist in the United States a federal corporation code, although the argument for the creation of such a code has been long and persistent. ${ }^{4}$ Also on a state level, the unitary nature of the United States capital and securities markets has effectively precluded a piecemeal incorporation of securities provisions within the respective states' corporations codes; such an attempt would clearly be a futile endeavor. Yet, while developing apart from classical corporation laws in the United States, federal securities laws over the years have in reality created its own body of "federal corporation laws", having a direct and immediate impact upon corporate behavior and decision-making.

2. See generally (i) Securities Act of 1933, 15 U.S.C. ss.77a-77aa (1970) (hereinafter the "1933 Act"); (ii) Securities Exchange Act of 1934, 15 U.S.C. ss.7a to $78 \mathrm{hh}-1$ (1970 (hereinafter "1934 Act"); (iii) Public Utility Holding Company Act of 1935, 15 U.S.C. ss.79 to 79z-6 (1970); (iv) Trust Indenture Act of 1939, 15 U.S.C. ss.77aaa$77 \mathrm{bbbb}$ (1970); (v) Investment Company Act of 1940, 15 U.S.C. ss.80a-1 to 80a-52 (1970); and (vi) Investment Advisers Act of 1940, 15 U.S.C. ss.80b-1 to $80 \mathrm{~b}-21$ (1970). The rules under these acts may be found in Title 17 of the Code of Federal Regulations (hereinafter "C.F.R.") with the designation of the rule appearing after a prefix applicable to the pertinent act. The prefixes are 230 for the 1933 Act; 240 for the 1934 Act; and 275 for the 1940 Act.

3. See Conard, "Overview of the Laws of Corporations", 71 Mich. L. Rev.621, at $658-660$ (1973). For particular comparison of U.S. and U.K. practice see Knauss, "Securities Regulation in the United Kingdom: A Comparison with United States Practice", 5 Vand. J. Trans.L. 47 (1971). Also see generally Leleux, "Corporation Law in the United States and the E.E.C.", 5 Comm. Market L. Rev. 133 (1967). On U.S. state "blue sky" laws see generally Loss and Cowett, Blue Sky Law (1958).

4. For recent discussion see especially Cary, "Federalism and corporate law: reflections upon Delaware", 83 Yale L.J. 663 (1974) and Jennings, "Federalization of Corporation Law: Part Way or All the Way", 31 Bus. Lawyer 991 (1976). 
The Acts. The 1933 Act is cssentially event oriented; that is, it is designed to achicve truth in securities in connexion with a "public distribution" of securitics (generally as evidenced by a formal public offering process) by providing full and fair disclosure to the investing public. The basic dictate of the 1933 Act (as embraced in s.5 thereof) is that evcry offer of salc or sale of a security must mect the formal regislation requirements of the Act, unless an exemption can be found. As will be discussed subsequently in $\mathrm{s.V}$, an unregistered distribution of sccuritics which docs not meet a statutory cxemption may trigger various sanctions and liabilities. Moreover, cven if a distribution is registercd or can claim a statutory excmption, this fact will not preclude the applicability of certain broad anti-fraud provisions of the federal securities laws (given that there exists an underlying security).

The 1934 Act is ycared to multi-faceted aspects concerning the trading in securities subsequent to an initial distribution. This Act covers such matters as regulations of stock cxchanges (s.6 of the Act), over-the-counter markets (s.5), broker-dealers (ss.7-11), on-going registration and disclosure requirements respecting certain corporate securities (ss.12(g), 13 and 15(d)), proxy solicitations (s.14) and security tradings by corporate "insiders" (s.16). In addition, the 1934 Act established the Sccuritics and Exchange Commission ("SEC"), the federal administrative agency having primary responsibility for the implementation and enforcement of the federal securities laws.

Continuous and Coordinated Disclosure System. The thread that runs throughout the 1933 and 1934 Acts is the concept of "disclosure". The statutory objective of the Acts is not to make determinations into the merits or non-merits of a particular investment security, but is to provide information to the public investors so that they may make informed investment decisions and to insure that the integrity of the securities market is maintained. The material facts about sccurities having been told, the decision is then left to the investor.

The 1933 Act disclosure provisions attempt to provide, through the use of the registration statement and prospectus, all material information to the investor with respect to the initial distribution of a security. The 1934 Act has cvolved over the years to provide material disclosure to the public investor subsequent to the public offering and to the trading markets themselves. Recent cmphasis in federal securities laws is, however, to stress a coordinated system of disclosure between the 1933 and 1934 Acts, with the continuous reporting requirements of the 1934 Act becoming the primary tool in insuring full and fair disclosure to the investor and the trading markets.

Section 12 of the 1934 Act contains the primary disclosure re- 
quirement, by corporations with assets of over $\$ 1,000,000$ and having a class of equity securities held by 500 or more stockholders must formally register such equity securities with the SEC and provide the public with continuous disclosure. While technically it is corporate securities that are registered, in reality it is the corporation itself which must comply with the periodic filing and reporting requirements of the 1934 Act, the most notable of which are the filing of annual reports with certified financial statements on Form 10-Q, and reports of current developments on a timely basis on Form 8-K.

While the federal securities laws do not purport to be regulatory in nature, the expansion of the disclosure system has had a definite regulatory effect upon the day-to-day activities of corporations coming within the ambit of the federal securities legislation. The SEC continues to evaluate the impact and viability of the use of a coordinated and continuous disclosure system in protecting the investing public and the integrity of trading markets, and has recently completed a comprehensive study of this system. 5

II.

\section{Recognizing A Security}

The determination of whether or not a given business transaction involves a "security" is crucial. A basic rule of federal securities law is that every offer to sell or sale of a security must meet the registration requirements of the 1933 Act, unless a specific exemption can be proven. Moreover, even where an exemption can be shown, this is merely an exemption from the registration requirements of the 1933 Act and not from the broad anti-fraud provisions of the federal securities laws.

\section{(A) Respective Definitions}

Section 2(1) of the 1933 Act defines a security as follows: "SECTION 2. When used in this title, unless the context otherwise requires--

(1) The term 'security' means any note, stock, treasury stock, bond, debenture, evidence of in-debtedness, certificate of interest or participation in any profit-sharing agreement, collateral-trust certificate or subscription, transferable share, investment contract, votingtrust certificate, certificate of deposit for a security, fractional undivided interest in oil, gas, or other mineral rights, or, in general, any interest or instrument commonly known as a 'security', or any certificate of interest or participation in, temporary or interim certificate for, receipt for, guarantee of, or warrant or right to subscribe to or purchase, any of the foregoing." (Emphasis added.) 
'This definition roughly parallels and has generally been equated with the definition of a security contained in s.3(a) (10) of the 1934 Act.

These corresponding definitions embrace traditional forms of securities (e.g., stocks, bonds, debentures and warrants); however, they also contain such expansive terms as "investment contract" or "any instrument commonly known as a security", which terms have often been used interchangeably by the courts to embrace a sundry array of business activities. It is from an examination of these latter two species of a "security" (which have embraced such transactions as certain franchise agreements, interests in certain agricultural ventures, multi-level distributorships, whiskey warehouse receipts, variable annuity plans and various real estate arrangements, etc.) that a foreign observer can begin to appreciate the broad substantive scope of the federal securities laws.

\section{(B) Historical Perspective of "Investment Contract"}

Congressional desire to include such catch-all phrases as "investment contract" or "any instrument commonly known as a 'security' " under the statutory definition of a security, appears to have been designed to provide a broad framework within which the courts may establish flexible standards and criteria so as to insure that ingenious schemes which are virtually identical to the more traditional forms of securities transactions, but are called by some other name, do not escape the remedial embrace of the federal securities laws.

The historical roots of the term "investment contract" stem from the 1917 Minnesota legislature's incorporation of this term in a statute defining "investment company" and "dealer". The use of the term steadily spread throughout the various state "blue sky laws" and was ultimately adopted by Congress when it enacted the federal securities laws.

On a purely literal analysis, the words "investment" and "contract" would make it appear that any contractual arrangement whereby capital was employed to produce some economic benefit could be found by the courts to constitute a security. As seen in the early state cases which grappled with the term "investment contract", the courts had considerable problems in setting some boundaries to the term. But, very early judicial interpretations indicate that, despite the broadness of the term, not every investment is a security. ${ }^{6}$

6. On "investment contract" see generally Symposium, "Interpreting the Statutory Definition of a Security, Some Pragmatic Considerations", 6 St. Mary L.J. 96205 (1974); Hannon and Thomas, "The Importance of Economic Realty and Risk in Defining Federal Securities", 25 Hastings L. Rev. 219 (1973); Tew \& Freedman, "In Support of SEC $v$. Howey Co.: A Critical Analysis of the Parameters of the Economic Relationship between an Issuer and the Securities Purchaser", 27 U. Miami L. Rev. 407 (1973); Long "An Attempt to Return 'Investment Contract' to the Mainstream of Securities Regulation", 24 Okla.L.Rev. 135 (1971); and Coffey, "The Economic Realty of a 'Security': Is there a More Meaningful Formula?" 18 W.Res.L.Rev. 367 (1967). 
(C) The Howey Case

In 1943, the United States Supreme Ciourt, in SEC v. C.M. Joiner Leasing Corp. (320 U.S. 344) issued its first opinion interpreting the term "Investment contract." 'I his case centered around a promotional scheme to sell to the public oil leases, accompanied by representations that defendants would drill a test well which would prove the productivity of the vendee's acreage. The purchasers resided throughout the country, many at a considerable distance from the promised test well-site. There was no indication that any of the purchasers were capable of realizing a profit on their purchase through their own skills.

In defining the term "investment contract", the Court chose to rest its holding on general policy grounds, suggesting a caseby-case analysis:

"The test rather is what character the instrument is given in commerce by the terms of the offer, the plan of distribution, and the economic inducements held out to be the prospect. In the enforcement of an act such as this it is not inappropriate that promoters' offerings be judged as being what they were represented to be." (Emphasis added.) 320 U.S. 344 , at 352,353 .

In Joiner the Court found the economic realities of the situation indicative of a security as the "trading in these documents had all the evils inherent in the securities transactions which it was the aim of the Securities Act to end."

Three years later the Supreme Court, in the 1946 case of SEC v. W.J. Howey Co. (328 U.S. 293), specified the distinctive elements of an "investment contract". In Howey, defendants owned large tracts of citrus acreage in Lake Country, Florida. Defendants offered to the public both a land sales contract and a service contract and informed potential buyers that an investment in a small citrus grove was not economically feasible unless service arrangements were also made. The average size of the tracts sold to the public was 1.33 acres, and parcels as small as 0.65 of an acre were conveyed. Although the purchaser, upon full payment, received a warranty deed to his small tract, the service contract conveyed a leasehold interest back to defendants. Defendants were given complete discretion and authority over cultivation, harvesting and marketing. The landowner did not even have the right to enter upon his premises. There was no right to specific fruit (all the produce was pooled), and the defendants disbursed a share of the net profits to the landowner in accordance with output from the individual parcels.

As in Joiner, it was impractical in the Howey situation for the purchasers to participate in development of their own land because of their lack of sophisitication, absentecism and the economic difficulties of piecemeal working of the land. Relying heavily 
upon prior blue sky laws, a Minnesota Supreme Court decision, and the statutory aims of the 1933 Act, Justice Murphy in Howey set forth the following formula:

"[A] n investment contract for purposes of the Securities Act means a contract, transaction or scheme whereby [ (1) ] a person invests his money [ (2) ] in a common enterprise and [ (3) ] is led to expect profits [ (4) ] solely from the efforts of the promoter or a third party, it being immaterial whether the shares in the enterprise are evidenced by formal certificates or by nominal interests in the physical assets employed in the enterprise." 328 U.S. 293 at 298.

Justice Murphy was particular in noting that the above test "necessarily underlies this Court's decision in SEC v. Joiner Corp. . .,", thus disclaiming the formulation of a new test.

\section{(D) Summary of Four-Pronged Howey Test}

In summary, the Howey "investment contract" test requires four elements: (1) the investment of money, (2) in a common enterprise, (3) with the expectation of profits, (4) solely from the efforts of others.

(1) The investment of money. An investment contract must be more than simply a payment of money, for it is more than just a commercial transaction. It involves the transfer of money to an enterprise with the understanding that the money will be used to promote the business of that enterprise and with the further understanding that the money will be used to promote the business of that enterprise and with the further understanding that the invested fund will be tied to the destiny of the enterprise. Thus, an investment contract can exist only when money is placed at the risk of an enterprise (i.e., "invested"), perhaps the single most important characteristic which distinguishes a security from the host of other business transactions.

A second significant point is that of the use of the word "money": Does "money" mean actual cash or "money's worth"? The soundest line of argument is to the effect that "money" is synonymous with "money's worth."

(2) Presence of a common enterprise. Another indispensable element of the Howey test is the requirement of "common enterprise." This term is not precisely defined, and has posed considerable problems for the courts over the years. However, the meaning of the phrase "common enterprise" can be drawn from looking at the facts of the Supreme Court cases which have dealt with the term. From each of these cases, it is evident that, at minimum, the Court will require the presence of a group of investors linked together by a common business scheme in order to 
find the existence of the element of common enterprise. The commonality must be horizontal and not simply vertical between purchaser and seller [Cf., however, Bonnet, "How Common is a Common Enterprise," (1974) Ariz.St.L.J. 339] .

(3) Expectation of profits. It is evident under the Howey test that there must be an expectation of appreciation above and beyond the initial value given. For example, in the Joiner case, the profit expected by each individual investor was the appreciation of the market price of his individual acreage. In addition, as suggested by the Supreme Court in both Howey and subsequently in the 1975 case of United Housing Foundation, Inc. v. Forman, 421 U.S. 837 (see infra), this expectation of profit must be the primary, if not sole, motivating force behind the investment.

(4) Profits will result "solely from the efforts of others." As discussed below, with respect to the Glenn Turner case, the Ninth Circuit applied a "managerial profits test" in attempting to characterize the economic realities of the pyramid sales scheme involved in that case. The Ninth Circuit's alternative approach to the fourth Howey criteria was acknowledged by the Supreme Court in Forman, though the Supreme Court expressed no view on the correctness of this approach.

The inference of the Supreme Court appears, however, to be that the "solely from the efforts of others" test should not be interpreted literally to the point of frustrating the overall attempts of the courts to ascertain the true economic reality of the situation. Perhaps one reason the Supreme Court did not take a firm position is that "the essential managerial efforts test" itself poses many difficult conceptual and practical problems. For example, whose and what efforts are in fact essential in terms of the success or failure of a business scheme? Is the term "essential" to be equated with "controlling" or is it something else?

(5) Other relevant considerations. At minimum, the seller's characterization of the scheme is evidentiary in showing whether a security exists. Moreover, the Court in Forman appears to focus upon economic inducements made by the seller, along with the motives of the purchaser.

\section{(E) Post Howey Interpretations.}

The Howey test has been the subject of considerable discussion and criticism over the years. The California Supreme Court in Silver Hills Country Club v. Sobieski, 361 P.2d 906 (1961) went so far as to raise the possibility that an emphasis on profit reliance, as in Howey, misses the mark in ascertaining the existence of an "investment contract", and to postulate the so-called "risk cap- 
ital" test as an alternative approach to the profit-making requirement set forth in Howey. The court found a strict interpretation of the Howey test to be nonexclusive, and looked for a test which would protect the investing public in those situations where the "profit seeking" motive was not primary. Stated simply, the "risk capital" test asks: is substantial venture capital being supplied by an investor who has little or no control over the venture? This test is not designed to do away with the Howey criterion of a profit-making motive, but sets forth an additional test by which the courts may judge novel promotional schemes for distributing securities to the investing public by focusing on the actual "risk" of the investment. Certain federal courts have looked favorably upon use of this test [e.g., Great Western Bank \& Trust v. Kotz, 532 F.2d 1252 (9th Cir., 1976)] .

In the 1973 Ninth Circuit decision in SEC v. Glenn W. Turner Enterprises, Inc., 474 F. 2d 476, (a case involving an elaborate promotional pyramid sales plan) the court stated that the "solely from the efforts of others" test in Howey can "lead to unrealistic results" if applied dogmatically. The Turner case did not attempt to give a complete and universal definition to "investment contract"; nor did it purport to reject the Howey test. Relying on the remedial nature of the federal securities statutes, public policy considerations and the Supreme Court's warning that flexibility be accorded the definition of a security, the Ninth Circuit promulgated what it considered a realistic test of defining the "efforts" test of Howey as "whether the efforts made by those other than the investor are the undeniably significant ones, those essential managerial efforts which affect the failure or success of an enterprise." The facts in Turner indicated that there was an investment in money by public investors in a common enterprise with expectations of profit. Moreover, as noted by the trial court's findings, which apparently were fully supported by the record, defendants' scheme was a gigantic and successful fraud.

\section{(F) Howey Remains Law; Forman Case.}

Despite whatever judicial interpretations of Howey there have been, the Howey test remains the primary test for determining the existence of an "investment contract". Subsequent to Howey, the Supreme Court on four separate occasions has considered and defined "investment contract" in light of the four-pronged Howey test. Particularly noteworthy is the Supreme Court's most recent decision in 1975 United Housing Foundation, Inc. v. Forman (421 U.S. 837). ${ }^{7}$

7. In addition to Forman case cited in text, see SEC $v$. Variable Annuity Life Ins. Co. of America, 359 U.S. 65 (1959) re variable annuity contracts; SEC v. United Beneficial Life Ins. Co., 987 U.S. 202 (1967) re "flexible fund" annuities; and Tcherepnin v. Knight, 389 U.S. 332 (1967) re withdrawable capital bank shares. 
In the Forman case, the Supreme Court again espoused the Howey test as the guiding principal in ascertaining the presence of an "investment contract". In Forman the Court held that shares of "stock" entitling a purchaser to lease an apartment in a cooperative housing project financed and supervised by the state were not securities within the meanings of the 1933 and 1934 Acts. Relying on the fact that the sales in question could not be held for profits, the district court had ruled that the shares were not securities and dismissed the complaint. However, the Second Circuit reversed and held the "stock" to be securities by their literal designation and because the transaction involved an "investment contract". 'The Second Circuit did not use the Howey test as its guide and the Second Circuit found that while the shares could not be held for monetary profit, there was an expectation of profits from other sources (e.g., rental reductions resulting from income produced by rental of commercial facilities on the premises). that

The Supreme Court reversed the Second Circuit, emphasizing

"This test, in shorthand form, embodies the essential attributes that run through all of the Court's decisions defining a security.

The touchstone is the presence of an investment in a common venture premised on a reasonable expectation of profits to be derived from the entreprenurial or managerial efforts of others. By profits, the Court has meant either capital appreciation resulting from the development of the initial investment, . . . or a participation in earnings resulting from the use of investors' funds, ... In such cases the investor is 'attracted solely by the prospects of a return' on his investment." 421 U.S. 837 at 852 .

The Supreme Court in Forman rejected the Second Circuit's broad interpretation of profits as being equated with any economic benefit. Instead, the Court held that profits are to be construed in the sense of capital appreciation resulting from the devclopment of the initial investment or a share on earnings and profits. Further, in analyzing the concept of expectation of profits, Mr. Justice Powell was particularly concerned with the economic inducements made to the investors and to the motives of the purchasers themselves. Reasonable inference from the decision is that the expectation of profits must be primary, if not the sole, motivating factor for the investors.

\section{(G) Comment: Commercial v. Investment Approach}

An interesting approach has been developed by certain courts in determining the existence of a "security" by characterizing the given transaction as either primarily commercial (i.e., not a security) or investment (i.e., a security) in nature. This commercialinvestment test has been applied to date mainly with respect to the issuance of notes. 
The term "security" under both the 1933 and 1934 Acts explicitly includes within its definition "any note or any participation in a note." The crucial question therefore revolves around whether the underlying note constitutes a security. In recent years there has been considerable controversy as to what notes are in fact securities. The prevailing view appears to be that a note should be viewed in context of the entire economic reality of the transaction: that is, whether the note is primarily "commercial" or "investment" in nature. ${ }^{8}$ Not every note, even if literally within the definition of the securities laws, is a security. The commercial context of the underlying transaction has to be evaluated. Notes issued for personal loans and consumer instalment purposes are not securities. Notes that are issued for investment and business acquisitions, as well as commercial paper sold outside the normal institutional markets, may be securities.

The courts appear to be placing a continuing reliance upon this so-called "investment-commercial" test, ${ }^{9}$ and it is likely the courts may be looking to this distinction with respect to other business activities which may involve a security. However, the Second Circuit has recently concluded that "the best alternative now available may be in greater recourse to the statutory language" of the securities laws, wherein a defined transaction is to be deemed a security "unless the context otherwise requires." This latter phrase qualifies the definition of a "security" contained in both the 1933 and 1934 Acts. 10

\section{(H) Example of Scope: Real Estate Transactions:}

As indicated above, the federal securities laws have been applied to a wide variety of business activities not normally preceived as involving a security. One such area of activity is real estate transactions, which traditionally have been viewed as commercial in nature. This area is particularly germane to this study, because of the increasing number of foreign investors participating in real estate transactions in the United States.

Perhaps the most common form of real estate syndication in the United States is that of a limited partnership, which by its very nature is a passive equity-type investment with sole reliance upon the efforts of a third party (the general partner) for the management and control of the investment property. As such, limited partnership interests will generally meet with a strict application of the Howey test. [See SEC. Final Guidelines for Disclosure

8. Cf. however, Lehigh Valley Trust case, 409 F. 2d 989 (5th Cir. 1969).

9. See inter alia, Andrews v. Blue, 489 F.2d 367 (10th Cir. 1979); Kerbs v. Fall River Industries, Inc., 502 F.2d 731 (10th Cir., 1974); and Zabriskie v. Lewis, CCH Fed.Sec.L.Rep. No.94,902 (1974); and Great Westerm Bank \& Trust v. Kotz, 532 F.2d 1251 (9th Cir., 1976).

10. See Exchange National Bank of Chicago v. Touche Ross \& Co., CCH Fed.Sec. L.Rep. No.95,614 (2nd Cir., June 9, 1976). 
In the Preparation of Registration Statements Relating to Interest in Real Estate Limited Partnerships, SEC Release 33-5465, March 1, 1974.] Moreover, while an interest in a joint venture or general partnership is normally the anthesis of an "investment contract," it is possible to use the joint venture vehicle to disguise what essentially is a passive investment. For example, if the joint venture interests are offered to a large number of individuals, it is unlikely that all of the joint ventures can be expected to participate in the management and control of the project. In securities cases, the courts have consistently looked to substance over form taking a liberal approach toward the remedial nature of the federal securities laws.

Another example of where a real estate transaction may involve a security is with respect to offers and sales of condominiums. As a general rule condominiums held as investments are not considered a security; however condominiums, coupled with various collateral service arrangements (e.g., rental pooling), may be deemed to be securities if they are offered and sold through advertising, sales literature, promotional schemes or oral representations which emphasize the economic benefits to the purchaser to be derived from the managerial efforts of the promoter, or third party designated or arranged for by the promoter in performing such services. [See generally SEC Release 33-5347, January 4, 1973, although it should be noted the SEC has recently ordered a halt on No Action Letters involving resort real estate interests]. A security is normally not involved when a person invests in real estate with the hope of earning profits as a result of a general increase in values concurrent with the development of the neighborhood, as along as he does not do so as part of an enterprise whereby it is expressly or impliedly understood that the property will be developed or operated by others. As such offerings of undivided interests in real estate will not normally create a security, unless coupled with some form of collateral arrangement whereby the promoter or nominee as lessee assumes primary responsibility of physical management of the property and distribution of the profits to the co-owners (see I Loss 494).

Additional areas of real estate activity wherein a security may be involved is with respect to marketing of mortgage notes and deeds of trust and certain sale and leaseback transactions. Interests in mortgages and deeds of trust qualify by definition of securities inasmuch as they would be "evidences of indebtedness" Ordinarily, however in the case of the initial issue of a mortgage note by buyer to seller, the transaction would be exempt from registration as it would not involve a public offering. However, as early as 1958 the SEC had expressed concern over the increasing number of hold trust deeds and mortgages which were being offered for sale under circumstances indicating that they involved "investment contracts" which should be registered. Respecting sale or lease- 
back arrangements, these would generally not constitute an "investment contract", insofar as the buyer does not look to the continuing management efforts of the seller for return of profit. However, several recent SEC No Action Letters suggest that under certain circumstances an "investment contract" may be involved.

As a general guide in determining whether a real estate transaction (or for that matter any other business transaction) involves an investment contract (ergo a "security") the cases indicate that form will give way to substance and economic reality. To rely on a strict and enforceable interpretation of Howey would appear injudicious, even in light of the recent Forman case. In any event if there appears to be even a tinge of a passive investment element in a real estate transaction, the question should be raised for further analysis as to whether a security is involved. ${ }^{11}$

\section{III}

\section{Extraterritorial Applicability}

Knowing the substantive content of U.S. securities laws is one matter, knowing the embrace of such laws in jurisdictional terms is another. To many foreign observers, the broad approach taken by U.S. courts with respect to the extraterritorial extension of the federal securities laws is most disturbing. ${ }^{12}$

A threshold consideration respecting extraterritorial application of the Federal Securities laws is the limitations, if any, placed upon such application by requirements of international law. With such international perimeters in mind, consideration will then be made of (i) the statutory bases of extraterritorial application and (ii) selective cases on the question decided by United States courts.

Regarding the first question, it is clear that professionals, including broker/dealers and banks are persons who "transact business in securities." In Ferraioli [CCH FedSecL.Rep. No.91615 (1965)], the New York district court extended the scope of s.30(b) to non-professionals who had entered into a single isolated sale of securities. However, the Second Circuit in Schoenbaum, supra, expressly rejected this broad interpretation of s.30(b) given by the court in Ferraioli; the Second Circuit limited the s.30(b) exemption to persons generally engaged in a business in securities through foreign securities markets and not to persons

11. See generally Rifkinds \& Borton, "SEC Registration of Real Estate", 27 Business Lawyer 649 (1972); Wertheimer \& Mark, "Special Problems of Unregistered Real Estate Securities", 22 U.C.L.A. L. Rev. 1191 (1975), and comment; "Securities Regulation of Real Estate Programs", 27 Ark.L.Rev. 651 (1973): Also see Burton, Jr. "Real Estate Syndications in Texas: An Examination of Securities Problems", 51 Texas L. Rev. 239, 244 (1973).

12. For foreign criticism of U.S. Approach generally see Jennings, "Extraterritorial Jurisdiction and the United States Antitrust Laws", XXXIII Brit. Yb.Int $l$ L. 146 (1957) and Mann, "Anglo-American Conflict of International Jurisdiction", 13 Int 7 \& Comp. L.Q. 1460 (1964). 
who engaged in isolated foreign transactions. In fact, in Schoenbaum the court went so far as to hint that the exemption should be limited to securities transactions effected on foreign exchanges - a view with no apparent statutory basis.

\section{(A) Limitations Under International Law.}

General Principles. The fact that valid international law is part of U.S. municipal law is established. The problems that American courts have had in this respect, particularly in the area of jurisdiction, stem primarily from the difficulties in determining exactly what may or may not be international law on a given point.

Traditionally, the United States has primarily relied upon the territorial principle of jurisdiction for applying U.S. laws to situations involving a foreign element. However, over the years the territorial principle itself has been expanded in several ways. The socalled subjective territorial principal (as encapsulated in No.17 of the Restatement of the Law, Second, Foreign Relations of the United States), has been developed to establish the jurisdiction of a state to an act commenced within the state, but completed abroad. The objective territorial principle (as delineated in No.18 of the Restatement would confer jurisdiction to a state respecting an act commenced without the state but consummated, or having an impact within its territory.

While an assertion of jurisdiction under the objective territorial principle purports to be "territorial," in fact it is not, as nothing need necessarily be done in the territory. Use of the objective territorial principle has, however, been traditionally subject to limitations imposed by United States courts. First, the conduct and its effect must be "consistuent elements of activities to which the rule applies." The second test is that the effect within the territory must be "substantial." Thirdly, the territorial effect must "occur as a direct and foreseeable result of the conduct abroad." Finally, the rule of law of which the territorial state seeks to impose on conduct abroad causing effects in the territory must not be "inconsistent with the principles of justice generally recognized by the states that have reasonably developed legal systems." Such criteria are admittedly somewhat vague and nebulous. However, they do express the principle that there are limitations upon the extraterritorial applicability of domestic law.

The underpinnings of U.S. law respecting extraterritorial jurisdiction are found in the caselaw involving extension of jursidiction under the federal antitrust laws. ${ }^{13}$ It is from the perspective of this caselaw, that the courts have embarked upon their analysis of extraterritorial jurisdiction of the federal securities laws. While

13. See Inter alia U.S. v. Aluminium Co. of America, 148 F.2d 416 (2nd Cir. 1945) and U.S. v. Watchmakers of Switzerland Informatkon Center, Inc., 1963 CCH Trade Cases No.70,600 at 77,414, 77,457 (S.D.N.Y. 1962). See Report of the Attorney General's National Committee to Study the Antitrust Laws, at 76-77 (March 31, 1955), and Fulda \& Schwarts, Regulation of International Trade of Investment Ch. 2 (1970). 
subject to considerable international criticism, these underpinnings can find their counterparts in various foreign jurisdiction. ${ }^{14}$

\section{(B) Statutory Bases.}

1934 Act. Traditionally, the 1934 Act had been thought to apply only to transactions within the territorial limits of the United States. This normal presumption of territoriality was viewed as reenforced by the specific mandate of s.3)(b) of the 1934 Act. However, in recent years, the Second Circuit, beginning with the Schoenbaum case [405 F.2d 200 (1968)], has stood this traditional view on its head through a somewhat contrived rationalization (see infra.). In addition, until 1964, most of the provisions of the 1934 Act extended only to securities listed on a national securities exchange or, to a limited extent, to securities for which a registration statement had been filed under the 1933 Act. However, in 1964, s.12(g) was added to the 1934 Act which essentially requires all corporations (i) engaged in interstate commerce, or in a business affecting in terstate commerce, or whose securities are traded by use of the mails or any means of instrumentality of interstate commerce and (ii) which have total assets exceeding 1,000,000 dollars, to register each class of equity security held of record by 500 or more persons.

Thus, from a strict statutory focus, ss.30(b) and 12(g) are of primary concern in understanding the extraterritorial effects of the 1934 Act:

(1) Section 30(b). Section 30(b) of the 1934 Act provides that the provisions of the Act or any rule or regulation thereunder shall not be applicable "to any person insofar as he transacts a business in securities without the jurisdiction of the United States, unless he transacts such business in contravention of such rules and regulations as the Commission may prescribe as necessary or appropriate to prevent evasion of this title." In examining this provision two basic questions arise: (a) who is encompassed by the clause "any person insofar as he transacts a business in securities," and (b) what are the jurisdictional limits of s.30(b).

What exactly "jurisdiction" means for purposes of s.30(b) is unclear. The courts infer that it is something more than territorial competence; yet logically and legally it makes no sense to view it as full jurisdiction in an international law sense, for then Congress would be granting authority beyond its own limits of power. Whether or not the phrase "without the jurisdiction of the United States" is to be viewed in terms of territorial limitation or more in

14. For example of foreign counterparts see Inter alia Allen, "The Development of EEC Antitrust Jurisdiction Over Alien Undertakings", 2 Legal Issues of European Integration 35 (1974). 
terms of jurisdiction in the public internation law sense is still an unsettled question. ${ }^{15}$

(2) Section 12(g). Unlike s.30(b) of the 1934 Act which requires positive action by the SEC if the Act is to be applied to persons transacting a business in securities without the jurisdiction of the United States, $s .12(\mathrm{~g})$ requires all corporations having securities coming within the terms of such section to register each class of equity securities held by more than 500 holders of record unless the SEC chooses to take affirmative action to exempt a foreign issuer. Section $12(\mathrm{~g})$ is accordingly given a presumptively extraterritorial application by Congress, to be modified only by the SEC.

Effective May 31, 1967, SEC Rule 12g3-2 was adopted. (SEC Release No.34-8066.) This detailed regulation requires all foreign issuers of a class of securities held by 300 or more United States residents to comply either with $s .12(\mathrm{~g})$ or some substitute registration requirement. Issuers with more than half their outstanding voting securities held directly or indirectly by United States residents, and whose businesses are either "administered primarily in the United States" or controlled by a board of directors, at least half of whom reside therein, must, with minor exceptions, comply fully with $\mathrm{s.12}(\mathrm{g})$. Almost all other private issuers have the choice of complying with $s .12(\mathrm{~g})$ or the more liberal requirements of the first clause of para. (b) of the regulation which requires filing with the SEC of that information required to be made public by (i) the law of the country of its domicile or in which it is incorporated or organized, (ii) the stock exchange on which its securities are traded and which were made public by such exchange, or (iii) that information distributed to its security holders. Formal registration of a foreign corporation under $\mathrm{s.12}(\mathrm{g})$ will result in the proxy provisions of the Act being applicable to any securities so registered and the short-term trading provisions of s.16(b) being applicable to $10 \%$ holders of such securities, although compliance does not constitute an admission that the foreign issuer is subject to the provisions of the 1934 Act.

1933 Act. The registration requirements of the 1933 Act generally apply to an offer or sale of a security involving interstate commerce or the use of the mails unless a specific exemption is found. As defined by s. 2(7) of the 1933 Act, the term "interstate commerce" includes "trade or commerce in securities or any transportational communication related thereto . . . between any foreign country and any state, territory or the District of Columbia". In this context, the 1933 Act may be construed to encom-

15. See generally Goldman \& Magrino, "Some Foreign Aspects of Securities Regulation: Toward a Revaluation of Section 30(b) of the Securities Exchange Act", 55 Va.L.Rev. 1015 (1969). 
pass virtually any offering of securities made by a United States corporation to foreign investors.

'I 'he SEC has, however, in the past taken the position that the registration requirements of s. 5 of the Act are primarily intended to protect American investors. While never admitting lack of jurisdiction, the Commission has not taken any action for failurc to register securities of United States corporations distributed abroad to foreign nationals, even though use of jurisdictional means may be involved in the offering. It is, however, assumed in these situations that the distribution is to be effected in a manner which would result in the securities coming to rest abroad. On the other hand, a distribution of securities by a United States corporation, through the facilities of a Canadian stock exchange, may be expected to flow in to the hands of American investors and therefore would be subject to registration. Simllarly, a public offering specifically directed toward American nationals abroad, including servicemen, would be regarded by the SEC as subject to registration if the interstate commerce jurisdictional provision is met [SEC Release No. 4708 (1964)] . Apart from such situations, however, it has been generally considered immaterial whether the otfering orignates from within or outside the United States, so long as the offering is made under circumstances reasonably designed to preclude distribution or redistribution of the securities within, or to the nationals or residents of, the United States. However, quite recently the SEC has been encouraging registration, even under these latter considerations.

\section{(C) Selected Cases.}

While it is outside of the scope of this article to deal at any length with the sundry cases considering the extraterritorial application of the federal securities laws, it may prove helpful briefly to consider a recent Second Circuit dealing with the subject, along with the recent Supreme Court decision in Scherk v. AlbertoCulver Co.. 16

(1) Bersch v. Drexel Frrestone, 519 F.2d $9 \% 4$ (2nd Cir. 1975). This suit, which appears to represent the maturation of the Second Circuit's (at least Judgc Friendly's) thoughts on the matter of extraterritorial application, eminates as a by-product of the infamous existence of Investors Overseas Services (IOS), with the added twist of being a class action involving U.S. plaintiffs resident

16. The Bersch case discussed in the text represents the culmination of a line of Second Circuit cases, particularly: Schoenbaum v.Firstbrook, 405 F.2d 200 (1968) and Leasco Data Processing Equipment Corp. v. Maxwell, 468 F.2d 1326 (1972). For additional securities cases involving problems of extraterritorial jurisdiction to those cited in notes and cited hereinafter, see inter alia Finch v. Marathon Securities Corporation, 316 F. Supp. 1345 (S.D. N.Y. 1970); Travis v. Anthes Imperial Limited, 473 F.2d 515 (8th Cir. 1973); S.E.C. v. Kasser. 391 F. Supp. 1167 (N.J., 1975) and Recamon v. Barish, 408 F.Supp. 1189 (E.D. Pa.1975); and SEC v. Churchill Forest Industries (Manitoba) Ltd., (3rd Gir., decided Nov. 8, 1976, Case No. 76-1322). 
in the United States, U.S. plaintiffs resident abroad, and non-U.S. plaintiffs resident abroad.

With respect to United States residents, the Second Circuit was reluctant to find jurisdiction solely on an alleged adverse impact on the American economy or American investors generally, especially in light of requirements of international law. The court did find subject-matter jurisdiction on the assumption that there was some mailing of prospectuses in the United States and some direct reliance upon them. Accordingly, the court endeavoured to satisfy the "eftects" and "direct and foreseeability" requirements of s. 18 of the Restatement, while funding significant activity within the United States.

Concerning the United States citizens resident abroad, the Court conceded that the federal securities laws were not necessarily designed to protect thousands of Americans residing in foreign countries against securities frauds by foreigners acting there. However, the Court found the presence of "preparatory activities" in the United States, which "significantly" contributed to the alleged losses, to be sufficient to trigger application of the jurisdiction of the securities laws when there is alleged injury to Americans abroad. But, without explanation or distinction, the court held such "preparatory activities" not to be sufticient by themselves for jurisdictional purposes with respect to foreigners abroad. In this respect, the court appears to consider the factor of nationality to be controlling.

While the Second Circuit requires a greater significance of U.S. activities respecting injury to foreigners abroad, as distinguished from American citizens abroad, the court made clear in this case, as well as in another case decided the same day by the court involving an international securities transaction, that "Congress did not mean the United States to be used as a base for fraudulent securities schemes even when the victims are foreigners, at least in the context of suits by the SEC or by named foreign plaintiffs". [See IIT v. Vencap, Ltd, 519 F.2d 100 (2nd Cir., 1975).] However, in such instances, the activities within the United States must be more than merely "preparatory" ones; they must relate to activities which may themselves be elements of an anti-fraud violation. As indicated by a recent Third Circuit Court case, the concept of "preparatory" activity is an elusive one, which may well be susceptible to "watering down" especially in an SEC injunction action (see Churchill case cited in note 16).

In summarizing the Second Circuit's view on the matter in Bersch, Judge Friendly postulated the following conclusions, in that the anti-fraud provisions of the federal securities laws:

(i) apply to losses of sales of securities to Americans resident in the United States whether or not acts (or culpable failures to act) of material importance occurred in this country; and

(ii) apply to losses from sales of securities to American residents abroad 
if, but only if, acts (or culpable failures to act) of material importance in the United States have significantly contributed thereto; but

(iii) do not apply to losses from sales of securities to foreigners outside the United States unless acts (or culpable failures to act) within the United States directly caused such losses. 519 F.2d 974 at 993 . In (1) and (iii) above, it appears the jurisdiction will be extended along farrly traditional territorial concepts of jurisdiction. However (ii) presents some rather bothersome implications, inasmuch as it appears to extend jurisdiction on the basis of nationality alone, which position may, in an international sense, be an excessive or exorbitant application of a state's jurisdiction and may well vilate certain existing U.S. bilateral treaty commitments.

(2) Scherk v. Alberto-Culver Co., 417 U.S. 506 (Supreme Court, 1973). This case centers around 1934 Act anti-fraud claims under s.10(b) brought against Scherk, a German national, by the American corporation, Alberto-Culver (which is a widely held public corporation, with stock listed on the New York stock exchange). Alberto-Culver had acquired three foreign enterprises from the defendant, which involved the issuance of securities (i.e., promissory notes) from the acquired assets. The purchase contract, which was negotiated partly in the United States, the United Kingdom and Germany, executed in Austria, and finally closed in Switzerland, contained express representations and warrants that certain trademarks acquired were free and clear of all encumbrances, an asserted fact which was subsequently found to be untrue. The purchase contract also contained (i) a choice of forum provision providing that any controversies or claims arising thereunder were to be arbitrated before the International Chamber of Commerce in Paris and (ii) a choice of law provision applying the state law of Illinois.

After Alberto-Culver discovered that the representations and warranties respecting the trademarks (which incidentially were licensed through manufacturers and distributors in the United States, in addition to those in Europe) were not valid, it tended the acquired assets back to Scherk and sough recission of the purchase contract. Scherk, however, refused, and Alberto-Culver accordingly brought suit in federal district court in Illinois. Scherk in turn moved for dismissal on the grounds of lack of both personal and subject matter jurisdiction. However the district court, and subsequently the court of appeals, rejected such motion, relying primarily upon the Supreme Court decision in Wilko v. Swan, $3+6$ U.S. 427 (1953), which they felt had held that an arbitration provision as provided for in the instant case would be unenforceable under the federal securities laws.

However, the Supreme Court took a different view of the facts and also of the interpretation of its Wilko decision, and held the arbitration provision to be enforceable. Writing for the majority, Justice Stewart distinguished Wilko, primarily on the fact that the 
instant case involved a "truly international agreement." The Court, reply on its earlier decision in Breman $v$. Zapata Off-shore Co., 240 U.S. 1 (1972), felt that the interest of international business transactions required that such forum and choice of law provision in the disputed arbitration clause be enforced. In so holding that such an arbitration provision could lawfully oust the jurisdiction of domestic courts and preclude the extraterritorial application of the federal securities laws, the Court also seemed impressed that in 1970 the United States had acceded to the Convention on the Recognition and Enforcement of Foreign Arbitration Awards.

All of the material facts in Scherk, except for the presence of the arbitration provision and a relevant international convention, would indicate that the jurisdictional requirements of the Schoenbaum-Leasco-Bersch line of cases would be satisfied. However, respecting what the Court dubs a "truly international agreement," the presence of suitable choice of forum and choice of law clauses appear to be sufficient to preclude the extraterritorial application of the federal securities laws.

While the main thrust of the Court is directed to the upholding of an international agreement, entered into at arm's length, Scherk and its implications remain somewhat unsettling. Firstly, there appears to be no determinative criteria as to at what point an agreement is in fact "truly international." Additionally, one cannot help wonder whether the size and sophistication of a company like Alberto-Culver, and its apparent ability to fend for itself, influenced the Court's decision. Would the holding in Scherk apply to a smaller domestic corporation having limited international experience, and would it apply in the situation of a United States individual? Also, Scherk leaves unclear whether or not the Court is implying that choice of law and conflicts of law rules should take precedence over general policy considerations of the federal

It should be noted that in writing for the four dissenting members of the Court, Justice Douglas vigorously rejected the majority's dichotomy between domestic and internation agreements. Justice Douglas left no doubt that he felt subject-matter jurisdiction existed in the instant case in the United States courts. ${ }^{17}$

\section{(D) Observations.}

From an examination of the cases and relevant statutes referred to above, the following observations may be derived:

(1) The position of American jurisprudence remains that, absent specific or implied congressional intent, the presumption is that federal law applies only within the territorial limits of the

17. For further discussion of Scherk see inter alia Note: 16 Harv. Int 7 L.J. 705 (1975). For sharp criticism of case see Comment: "Scherk v. Alberto-Culver Co. and Arbitration Under the Securities Exchange Act: A Comity of Errors", 1 J.Comp.L. 100 (1975). 
United States. In the securities law area, this presumption will be rebutted at least where the interest of protecting American investors and the integrity of the United States securities market predominates.

(2) In recent cases the courts have primarily focused upon the subjective territorial principle as a basis for finding subjectmatter jurisdiction arising under federal securities laws, especially in the area of securities fraud. On the basis of traditional principles of territorial jurisdiction, as embodied in s.17(a) of the Restatement, the subject provisions of the federal securities laws would be applicable when the violative transaction occurs entirely or substantially within the territory of the United States, even when the plaintiff and the only parties injured are predominately foreign. The difficult cases arise in determining the nature and extent of domestic activity for triggering provisions of the federal securities laws where conduct in the United States is minimal. It would appear that such conduct should be significant, essential and necessary in relation to the violative transaction (and not merely incidental or "preparatory" U.S. activity although the material content in the notion of "preparatory" appears rather loose). Clearly, listing on an American stock exchange would be one connecting factor, but substantial conduct may well consist of something less. However, the SEC's position that the use of interstate commerce facilities by itself is sufficient domestic activity strikes a very nervous note.

(3) On the basis of Bersch, it appears that the Second Circuit may be willing to extend jurisdiction in instances involving U.S. citizens abroad, primarily on the basis of nationality. Such an extension may well be deemed an exhorbitant exercise of jurisdiction under international law.

(4) Acts not occurring within the United States may come under subject-matter jurisdiction if such act could have a "significant impact" within the United States with regard to the American investors, and extraterritorial application is therefore necessary to protect securities trading in the United States and/or American investors. Adverse impact alone does not appear to be sufficient by itself for invoking jurisdiction; there must be additional connecting factors. Moreover, s.18(b) of the Restatement would indicate that in addition to the significant impact there must exist a direct casual relationship, with the domestic impact occurring as a direct and foreseeable result on the conduct abroad. The courts (except perhaps in Bersch) however, seen: to focus solely on whether or not a significant impact has occurred. Such a broadening of the principles of s.18(b) appears to be unsupported by any principle of international law.

(5) The courts do not appear ready to permit the United States to be used as a base for fraudulent securities schemes even when the victims are foreigners, at least in the context of suits by 
the SEC or by named foreign plaintiffs. The question of the degree of significance of the U.S. activities appears to remain an open point.

(6) The scope of the s.30(b) exemption to the applicability of the 1934 Act is not entirely clear.

(7) It is also unclear whether there is a differing standard for extraterritorial application of the registration provisions of the 1933 Act from that applied in anti-fraud cases, and whether there are differing standards to be applied in a private damage suit from an SEC injunctive action.

(8) It is difficult to formulate any general principles of international law with regard to the extraterritorial application of municipal law. However, international law does appear to set some outer limits to the extent a domestic jurisdiction can extend its laws. Section 18(b) of the Fiestaterrient would appear to represent the broadest limits internation law would permit.

(9) In instances involving "truly international" securities transactions, the courts appear willing to permit parties in arm's length dealings to limit contractually the applicability of the federal securities laws. The full implication of the Supreme Court's decision in Scherk, however, remains unclear.

(10) The significance of coming under the subject-matter jurisdiction of the federal securities laws can be far-reaching; covering such diverse matters as fraud in securities transactions under Rule 10b-5 and other anti-fraud provisions of the 1933 and 1934 Acts, registration requirements under s.5 of the 1933 Act, reporting requirements under ss.12, 13 and 15 of the 1934 Act, controls on dispositions of restricted securities, proxy and tender offer regulations (including reporting of $5 \%$ or more ownership of registered securities), broker-dealer requirements, and rules on short-swing profits under s.16 of the 1934 Act.

\section{IV.}

\section{Note on Exemption From Registration}

As indicated above, every offer or sale of a security must meet the registration requirements of the 1933 Act unless an exemption can be proven. The most commonly relied upon transactional exemptions from the registration requirements of the $1933 \mathrm{Act}$ are: (i) the private placement exemption under s. 4(2) of the 1933 Act or new Rule 146; (ii) the intra-state offering exemption under s. 3(a)(11) of the 1933 Act or new Rule 145; and (iii) the limited $(\$ 500,000)$ offering exemption under s. 3(b) of the 1933 Act and Regulation A thereunder. It should be noted, however, that all exemptions under the 1933 Act are merely exemptions from the registration requirements of that Act and are not exemptions from 
liability or certain reporting requirements under the securities laws. Moreover, the burden of proof in establishing the existence of an exemption always rests on the claimant. In addition, because of the dual system of federal and state securities laws, one must separately look to the specific requirements of the relevant "blue sky" laws for exemption from the registration requirements under state law.

\section{(A) Federal Law - Private Placements.}

Section 4(2) of the 1933 Act exempts "transactions by an issuer not involving any public offering" from the registration requirements of s. 5 of this Act. Basically, this exemption was designed for use by large sophisticated institutional investors (e.g., insurance companies) and not for general use. Over the years, the courts had broadened the category of persons for whom the exemption is available; however, recently the courts have turned back toward a more restrictive usuage of the exemption. Moreover, recently the SEC has promulgated Rule 146 respecting exemption for private offerings (SEC Release 33-5487, April 23, 1974 , as amended by Release 33-5585).

(1) Section 4(2) and the statutory exemption. The 1953 U.S. Supreme Court case of SEC v. Ralston Purina, 346 U.S. 119, remains the leading case respecting criteria used in determining what constitutes a non-public offering under s. 4(2). First, do the offerees need the protection which registration affords; and second, have they access to the kind of information that would be available in the registration statement? In addition, over the years a number of criteria have been suggested for what distinguishes a private from a public offering including, numerical tests respecting offerings; need for information; access to and quality of information; dollar size of offering; and investment intent of purchasers. Moreover in a 19725 th Circuit decision, the court also considered the necessity of having some form of preexisting relationship between the issuer and offerees (see SEC v. Continental Tobacco, 463 F. 2d 137).

Despite many pitfalls surrounding the s. 4(2) exemption, many syndicators continue to rely on this statutory exemption primarily because of the strigency and technical complexity of Rule 146. If reliance on the staturory exemption is made, the following elements (by way of summary guildelines) should be considered:

(i) Each person to whom an offer is extended must be sophisticated enough to evaluate the proposed investment (a difficult and highly subjective determination);

(ii) The sellers must be able to testify under oath as to each offer extended - failure to identify each and every offeree would create the presumption that there may have been others and destroy the availability of the exemption;

(iii) All investors must be furnished with the same information which a 
registration statement filed under the Securities Act of 1933 would make available (another subjective determination);

(iv) The manner of the offering must be such that no means of public solicitation is involved;

(v) The number of offerees must be small (although no exact number has ever been agreed upon);

(vi) It is desirable that there be some preexisting personal or business relationship between the buyers and sellers, or among the buyers themselves;

(vii) All investors must purchase for investment only and not with a view toward resale or further distribution; and

(viii) The sellers must introduce affirmative evidence that no additional sales were contempated in the future.

(2) Rule 146 (Effective June 10, 1974). Seeking to create objective standards and eliminate uncertainty to the extent possible in the area of private placements, the SEC has (after extensive consideration and debate) adopted Rule 146, Transactions by an Issuer Not Involving Any Public Offering. While the SEC does not believe it possesses the rule-making power to extend the availability of the Rule to anyone other than an issuer, the unofficial SEC staff position is that s.4(2) of the 1933 Act is also applicable to controlling persons.

Under the Rule (effective with regard to offerings commencing on or after June 10,1974), all persons who claim the availability of the Rule would have the burden to establish that all of its conditions have been met. Moreover, because of the stringent requirements of the Rule (particularly regarding the type of information which must be furnished offerees), it is extremely difficult for a "non-public" enterprise to meet all of the conditions of the Rule. 18

18. Briefly, the conditions of the Rule, all of which must be met for the Rule to be available are:

(i) Numerical Limitation. There can be no more than 35 purchasers in any "offering" pursuant to the Rule.

(ii) Nature of Offeree. While with regard to numerical limitation' the Rule stresses purchasers, the main thrust of the Rule is still designed to protect the offerees. The Rule contains two alternative tests for qualification of offerees: (i) a person would qualify who by virtue of knowledge and experience in financial and business matters is capable of utilizing the furnished information required by the Rule in evaluating the economic risks and in making an informed investment decision; or (ii) a person would also qualify if he is able to bear the economic risks of the investment and if he relies on a qualified "offerce representative". The issuer or any person acting on its behalf must have "reas. onable grounds" to believe that such qualifications of the offeree are met prior to making an offer and prior to making a sale.

(iii) Limitation on Manner of Sale - No General Advertisement. The Rule provides that neither the issuer nor any person acting on his behalf shall offer or sell the securities by means of "any form of general advertisement". Such prohibition would include (but not be limited to) seminars or meetings or letters, circulars, notices, radio or television broadcasts, which are directed to any non-qualified offeree; however, the prohibition would not apply to qualified of ferees and where the communication is accompanied by an undertaking to furnish the information required by the Rule.

(iv) Offeree Representative. As defined by the Rule an "offeree representative" is a person who is not an affiliate (including officers, directors and $10 \%$ shareholders of 
The cornerstones of Rule 146 are (i) full disclosure to investors and (ii) close control to ensure that no offers are extended except to qualified investors. If these and certain other conditions are met, then an unlimited number of offers may be made, and up to thirty-five (35) sales may be consummated, without federal securities registration. The Rule contains no numerical limitation as to offerees, although there exists other criteria for determining qualified offerees.

It should be noted that Rule 146 would be non-exclusive of the s.4(2) statutory exemption. The fact that the issuer's transaction does not meet all the conditions of the Rule would not raise any presumption that the statutory s.4(2) exemption is not available for the transaction. However, in light of the recent case law in the area, a practitioner would be wise to weigh existing private placement situations in view of the Rule. "Substantial" compliance with Rule 146 may, arguably, be sufficient for proving up the statutory exemption under s.4(2).

\section{(B) Intrastate Exemption \& Rule 147.}

Section $3(a)(11)$ of the 1933 Act provides an exemption for intrastate financing with regard to "any security which is part of an issue offered and sold only to persons resident within a single State or Territory, where the issuer of such security is a person

issuer), associate or employee of the issuer, who has sufficient knowledge and expertise to evaluate the risks of the prospective of fering, and who is acknowledged by the offeree during the course of the transation to be his representative for the purpose of evaluating the risks of the investment. The acknowledgement of representation must be made for each prospective investment and before every sale.

$(v)$ Arcess to Information. There are two basic requirements as to furnishing information .. ierees: (i) an offeree or his representative must either be in a position to obtain the same kind of information that registration would provide or actually receive such information; and (ii) the issuer must make the opportunity available to the offeree or his representative to obtain additional information to verify the basic information furnished. An issuer subject to the reporting requirements of the 1934 Securities Act may satisfy the information conditions by providing each offeree with the information contained in the most recent 10-K Annual Report, Form S-1 or Form 10, in addition to furnishing information as to a description of the securities offered, intended use of proceeds, and any material adverse changes in the issuer's affairs not disclosed in the forms filed. The issuer must update this information if the proxy statement or required reports have been filed with the SEC since the filing of the annual report or registration statement. Non-reporting companies would be required to provide that information called for by the Schedule A of the Securities Act of 1933, except that where certified financial statements are not available and cannot be obtained without unreasonable effort or expense, those required by Regulation A under the 1933 Act may be provided.

(vi) Limitation on Disposition. The issuer or any person acting on his behalf must take "reasonable care" to assure that the purchasers are not underwriters (i.e.participating, directly or indirectly, in a public distribution of securities). Such reasonable care would include, but not necessarily be limited to (i) making reasonable inquiry to determine if purchaser is an underwriter; (ii) placing a legend on securities evidencing that they are unregistered and setting forth restrictions on transferability and sale; (iii) issuance of stop transfer instructions to transfer agent; and (iv) obtaining a written agreement from purchaser that the securities that the securities will not be resold without registration or an exemption therefrom. In addition, the issuer should take steps to determine whether the purchasers are to be the beneficial owners of the securities or whether they are acting for other persons. 
resident and doing business within, or, if a corporation, incorporated by and doing business within, such State or Territory". This so-called intrastate exemption has in the past been shied away from by most knowledgeable attorneys and issuers because of the uncertainity surrounding such notions as "part of an issue", "bona fide resident" for all offerees and purchasers, and "doing business within such state" [SEC Kelease 33-4434, (1961)].

Rule 147 has recently been promulgated by the SEC in an attempt to provide some objective standards for use of the intrastate exemption and to ensure that such exemption is used only for the purpose that Congress intended it (i.e., local financing of companies, primarily intrastate in character). Specifically, the Rule endeavors to set perimeters for the terms "part of an issue", "preson resident" and "doing business within" for purposes of s.3(a)(11) of the 1933 Act. ${ }^{19}$

'ine stated purposes of the Rule are: (1) to serve the public interest by protecting investors and providing more certainity in determining when the exemption provided by $s .3(\mathrm{a})(11)$ is available; (2) to enable local business seeking financing solely from local sources to determine with more certainty whether they may use the exemption and the registration provisions of the 1933 Act; and (3) to give more assurance that the exemption is used only for its intended congressional purpose of local financing of companies primarily intrastate in character.

While the Rule is stated to be non-exclusive, it is clear that all thoughtful attorneys will in fact treat it as an exclusive guide for the intrastate exemption. However, it appears to this writer that

19. Rule 147 (SEC Release 33-5450, CCH Fed. Sec. L. Rep. para. 2253) covers transactions involving offers and sales of securities which meet all of the following conditions:

(i) The issuer must be "Yesident" of the state or territory in which the securities are offered and sold. To satisfy the residency requirement, a corporation, limited partnership or business trust must be incorporated or organized pursuant to the laws of such state or territory. A general partnership, not formed under a specific state law, must have its principal office within the state. In addition, an individual deemed an issuer (e.g. promoter issuing preincorporation certificates) will be deemed a resident if his principal residence is in the state or territory.

(ii) The issuer must be doing business within such state or territory. To meet the "doing business within" condition, the Rule sets out three percentage requirements, all of which must be met: (a) at least $80 \%$ of issuer's gross

of which must be met: (a) at least $80 \%$ of issuer's gross revenues on a consolitated basis are derived from the state; (b) at least $80 \%$ of its assets on a consolidated basis are located within the state; and (c) at least $80 \%$ of the proceeds of the offering will be spent in connection with the issuer's business conducted within the state. In addition, the issuer's principal office must be located in the state.

(iii) The offerees and purchasers must be resident within such state. To meet this requirement a person must have his "principal" residence in such state.

(iv) Resales for a period of nine months after the last sale which is part of issue must be limited so as the securities will come to rest within the state. In this regard, the issuer will be required to take affirmative measures such as (a) placing a legend on the certificate, (b) issuing stop transfer instructions; and (c) obtaining oral representations from all purchasers as to their residence. In addition the issuer must disclose in writing these limitations on resale. The thrust of this requirement is to provide objective standards for determining when an issue "comes to rest". 
the new Rule in fact represents an even more restrictive and narrow view of the intrastate offering exemption than the already restrictive and narrow judicial and administrative interpretations of the exemption that existed prior to its adoption.

\section{(C) The Regulation A Offering.}

Pursuant to statutory authority to exempt certain small public offerings, the SEC has promulgated "Regulation A" which exempts from registration public offerings for the account of a company which do not exceed $\$ 500,000$ in the aggregate in any one year. If the securities are to be sold for the account of a holder other than the company, the aggregate offering price during any one year may not exceed $\$ 100,000$. Although Regulation A is technically an exemption from the registration requirements, considerable documentation is necessary to establish the exemption, and a Regulation A is sometimes referred to as a "mini" registration. An offering circular, which is similar to a prospectus, must be supplied to each purchaser except for Regulation A offerings not exceeding $\$ 50,000$ and filed with the regional SEC office.

The principal advantages of Regulation A offerings, as opposed to tull registration, are that the required financial statements are simpler and need not be certified, and overall expenses are usually less. Regulation A offerings are reviewed by the regional offices of the SEC and not by the Division of Corporation Finance in Washington, D.C., as are full registrations. In some cases Regulation $A$ offerings have the advantage of being processed more quickly than full registrations, depending on the regional office and the time of year. There is, however, some prejudice in the financial community against Regulation A offerings. Some reputable underwriters who participate in small intrastate issues will refuse to take part in Regulation A offerings and prefer full S-1 registrations even for offerings which would qualify under Regulation A.

The SEC is presently considering "upping" the dollar restrictions on the use of the Regulation A offering.

\section{(D) Problems of Integration.}

As a general rule, if a specific exemption from ' 33 Act registration is relied upon, the exemption will be lost if the offering is deemed to be part of a larger distribution of securities that does not qualify for the same exemptions. For example, an issuer cannot avail himself of two separate exemption (e.g., intrastate and private placement exemptions) for what is essentially one scheme of distribution merely because the entire distribution would not qualify entirely for either one exemption. The SEC will only permit use of two separate exemptions when one might be sufficient where there is strong business justification for split- 
ting an issue of securities [SEC Release 33-2029 (1939)] .

The problem of integration is a highly conceptual problem and hinges upon whether or not apparently separate securities transactions in fact constitute one common scheme of distribution. Factual elements which may be helpful in defeating an attempt to integrate are (i) whether offerings are made at different times; (ii) whether the projects are financially independent from each other; or (iii) whether or not the risks and success of each transaction are dependent on the fate of the other project. In essence, to have integration the facts must indicate a common scheme of distribution.

\section{V. \\ Note on Civil Liabilities}

(A) 1933 Act.

An offering that does not meet a statutory exemption and is not registered may trigger several sanctions:

(i) One danger is that the SEC may obtain an injunction against the issuer either for future violations of the law or for future sales of the securities - an increasingly real possibility.

(ii) A more serious problem is posed by the civil liability provisions of the 1933 Securities Act. In effect, the issuer may very well find himself offering and selling a "put"; that is, a sale of a security coupled with a guarantee that if the enterprise has a downturn and proves unsuccessful, the issuer will be obligated to repurchase the security.

Section 12 of the 1933 Act sets forth the basic recission right with regard to the sale of an unregistered security. Under s.12(1) of the 1933 Act, any person who offers or sells a security without making the required registration is liable to the purchaser for the amount paid for the security, plus interest, less any income received from the security, or for damages if the purchaser no longer owns the security. Liability is effectively absolute: the offeror's only defenses are to show that the particular security or transaction was exempt from the registration requirements of the 1933 Act or that the purchaser at the time of purchase had actual knowledge of the fact that the sale was in contravention of the law (see Jennings $\&$ Marsh 1031). Any legal action based upon this section must be instituted within one year after the violation upon which it was based, and in no event more than three years after the security was offered to the public (s.13 of 1933 Act).

In addition, the civil liabilities and broad anti-fraud provisions of the 1933 Act apply to the sale of securities by means of any communication that includes an untrue statement of a material fact or omits to state a material fact necessary to make the statements not misleading in the light of the circumstances under 
which they were made. In the event of a material misstatement or omission, the purchaser has rescission rights against the seller regardless of whether the transaction was exempt from the registration requirements of the 1933 Act (s.12(2) of the 1933 Act). Moreover, criminal liabilities arise under federal law for willful violations (s.24 of the 1933 Act).

\section{(B) 1934 Act - Kule 10b-5.}

The most pervasive of the armory of anti-fraud devices under federal securities laws is Rule $10 \mathrm{~b}-5$, as promulgated under $\mathrm{s.10B}$ of the 1034 Act. By definition, the Kule applies to a "purchase or sale" of any security, regardless of registration or the existence of an exemption.

During the 30 year period since a private cause of action was first implied under s.1UB and Rule 10b-5, a substantial body of case law and commentary has developed as to its elements, much of which has generated uncertainty and ambiguity as to actually how broad the scope of the Rule. 'l'his Rule has been used as a weapon with respect to such matters as (i) misrepresentations and omissions involving a purchase or sale, (ii) corporate mismanagement, (iii) manipulation, (iv) tipping and inside trading, (v) tender offers and exchange offers, (vi) activities of brokers and other fiduciaries, (vii) freezeout of minority shareholders, and (viii) various other activities which may involve fraud in a securities transaction. 20

Very recently, the Supreme Court appears to be implying that the Rule is, however, not to be used as a broad catch-all for every type of security or business abuse. ${ }^{21}$ Nevertheless, the Rule still remains a potent weapon in the hands of a party where there is (i) conduct by the defendant prescribed by the Rule, (ii) an actual purchase or sale of securities by the plaintiff in connection with such prescribed conduct, (iii) some form of scienter or its equivalent (i.e. reckless disregard) on the part of defendants and (vi) resulting damages to the plaintiff (see generally Bromberg and Jacobs, supra.)

20. See SEC Release No. 34-3230 (May 21, 1942). This Rule provides:

"It shall be unlawful for any person, directly or indirectly, by the use of any means or instrumentality of interstate commerce, or of the mail, or of any facility of any national securities exchange,

(1) to employ any device, scheme, or artifice, to defraud,

2) to make any untrue statement of a material fact or to omit to state a material fact necessary in order to make the statements made, in the light of the circumstances under which they were made, not misleading, or

(8) to engage in any act, practice, or course of business which operates or would operate as a fraud or deceipt upon any person, in connextion with the purchase or sale of any security."

21. E.g. Blue Chip Stamps v. Manor Drug Stores, 421 U.S. 732 (1975), which stressed a strict interpretation of the purchaser-seller requirement; Emst $\&$ Emst $v$. Hochfelder, 96 S.Ct. 1375 (1976), which held that scienter (and not mere negligence) is an essential element of a 10b-5 action; and Green v. Santa Fe (Sup. Ct. No. 75-1753, March 23, 1977), CCH Fed. Sec. L. Rep., which limited to relief under state corporate laws "freezeout" of minority interest under short-form merger statute. 
(C) Derivative Liability.

(1) Aiding and abetting. The notion of aiding and abetting first found its way into federal securities laws in SEC disciplinary proceedings, and was based by way of analogy to criminal cases. Aiding and abetting was subsequently recognized in 10b-5 private rights of actions, which relied mainly on tort theory rather than prior securities precedents.

Generally, a person aids and abets another person in breaching the federal securitiy laws when he knows or should have known that a violation is occurring and he renders substantial assistance either by taking an affirmative action or by remaining silent or inactive when he has a duty to speak or act. Aiding and abetting would itself be a breach of Rule 10b-5.

As strongly noted by the Fitth Circuit in 1975 in Woodward v. Metro Bank of Dallas, 522 F.2d 84:

"[B] efore someone can be caught within the net of aiding and abetting liability under Rule $10 \mathrm{~b}-5$, another party must have violated the securities laws, the alleged aider-abetter must be generally aware of his role in improper activity, and he must knowingly render substantial assistance."

Without these limitations, the Court felt the securities laws would become a snare for guilty and innocent alike.

There still remains, however, substantial dispute as to whether, or to what extent, silence or inaction can fulfill the requirements as to knowing, substantial assistance of the violation. Essentially, this issue turns on the nature of the duty owed by the alleged aider and abetter to the other parties of the transaction. The standards courts have used for measuring culpability by silence have varied. Some have declared without qualification that silence and inaction alone can create liability for aiding and abetting [e.g., Brennan case, 417 F.2d 147 (7th Cir., 1969)]. Other courts squarely reject the notion that inaction alone is enough, distinguishing the contrary authorities [e.g., Landry case, 486 F.2d 139 (3rd Cir. 1974)]. One court has suggested a rule imposing liability "only where it is shown that the silence of the accused aider and abetter was consciously intended to aid the securities laws violation" [SEC v. Coffey, 493 F.2d 1304 (6th Cir. 1974)] . Another court has held that liability for silence or inaction arises "only when a duty to disclose has arisen" [Strong case, 474 F.2d 747 (9th Cir. 1973)] .

(2) Liability of Controlling Persons. Section 30(a) of the 1934 Act predicates the liability of "controlling" persons under the Act:

"Every person who, directly or indirectly, controls any person liable under any provision of [the $1934 \mathrm{Act}$ ] or of any rule or regulation thereunder shall be liable jointly and severally with and to the same extent as such controlled person to any person to whom such controlled person 
is liable, unless the controlling person acted in good faith and did not directly or indirectly induce the acts or acts constituting the violation or course of action."

The difficulty with this Section is that no precision is given to who constitutes a "control" individual. The determination appears to be largely a factual one [see Klapmier case, $314 \mathrm{~F}$. Supp. 1360 (D. Minn. 1970)].

Under the 1934 Act, characterization as a "controlling" person may expose one to liability under (i) Kule $10 \mathrm{~b}-5$ if he engaged in the purchase or sale of securities; (ii) s.18(a) of the 1934 Act respecting filing of false or misleading public documents; or (iii) s.16 of the 1934 Act respecting short-swing profits. Under s.2U(a) a "controlling" person may avail himself of the defence (except with respect fo s.16, which imposes a strict liability) that he "acted in good faith and did not directly or indirectly induce the act or acts" in question; although such person bears the burden of proof [see Mader case, 461 F.2d 1123 (6th Cir., 1972)].

Being a controlling person also has significance under the 1933 Act in that he may have liabulity under ss.11 and 12 of such Act. Moreover, a controlling person may trigger disclosure respecting various documents under the 1933 and 1934 Act. A controlling person is also significantly impeded in disposing of his securities. $\angle 2$

(3) Statutory Underwriter. The notion of a statutory underwriter for purposes of derivative liability essentially goes to the validity of claiming an exemption from the formal registration requirements of the 1933 Act. If a statutory underwriter is found to exist in a given transaction, either of the frequently used exemptions under s.4 of the Act (i.e., Section 4(2) private placements or $s .4(1)$ regarding transactions by any person other than an issuer, underwriter, or dealer) cannot be claimed. As such, the concept of statutory underwriter operates effectively to control non-registered distributions of securities.

For purposes of claiming a s.4(1) exemption, the term "underwriter" means "any person who has purchased from an issuer with a view to, or offers or sells for an issuer in connection with, the distribution of any security, or participates or has a direct or indirect participation in any such undertaking, or participates or has a participation direct or indirect in the underwriting of such undertaking. . " Moreover, solely for purposes of defining the term "underwriter", the term "issuer" shall also include controlling persons. 'Thus a controlling person, even though he is not an issuer, underwriter or dealer may not be able to sell under s.4

22. See generally Sommer, "Who's 'In Cọtrol"?-SEC", in Selected Articles on Federal Securities Law, 195 (A.B.A., 1968). 
(1) if a statutory underwriter is involved in the transaction [sec Chinese Benevolant Association case, 120 F.2d 739 (2nd Cir., 1941)].

The crucial concept applied by the SEC in ascertaining the presence of a statutory underwriter is that of a "distribution". The SEC views those who participate directly or indirectly in a distribution of securities (whether formal or informal) as possible statutory underwriters. The SEC's interpretation refers to the distribution process as an integrated whole, and not to any isolated purchase, offer or sale for an issuer [see In the Matter of Ira Haupt $\mathcal{E}$ Co., 23 SEC 589 (1946)] .

If in fact a statutory underwriter is involved, s.4(1) exemption cannot be claimed. Moreover, if a person purchases from a controlling person in a private placement, but the facts indicate he did so with a "view toward distribution", he becomes in fact a statutory underwriter and loses his exemption along with that of the controlling person. In 1972, the SEC Rules 144 and 237 for the purpose of clarifying the concept of "underwriter" and facilitating the distribution of "restricted" (i.e., unregistered or control) securities. ${ }^{23}$

\section{CONCLUSION}

The development of United States securities laws remains peculiar to the American experience. However, the substantive and jurisdictional embrace of these laws has broad implications for transnational business activities involving United States connecting factors. An appreciation of these implications is essential for prudent business and legal decisions relating to such activities.

23. See SEC Release No. 33-5223 (effective April 15, 1972) CCH Fed. Sec. L. Rep. para 78,487 , as subsequently amended on various occasions through June 8,1976 (SEC Release No. 33-517, CCH Fed. Sec. L. Rep. para 80,601). The following is a guide to use of Rule 144:

1. Offer or sale of restricted securities of a reporting company by any person (whether issuer, "control" or "non-control" person) - Rule 144 applicable.

2. Offer or sale of restricted or non-restricted securities of a nonreporting company by a control person - Rules $144 \& 237$ not applicable - must seek private placement exemption.

3. Offer or sale of non-restricted securities of a reporting company by a "control" person - Rule 144 applicable (except for holding period). able.

4. Offer or sale of restricted securities by a non-control person - Rule 237 applic-

5. Offer or sale of non-restricted securities by a non-control person - Rules $144 \&$ 237 not applicable. Section $4(1)$ exemption available.

Note: Rule 144 is non exclusive; but safe course is to use 144 whenever possible. 